\title{
Outils intelligents et compétences élargies des opérateurs
}

Rhazi Attabou et Robert Chabot

\section{(2) OpenEdition \\ 12 Journals}

Édition électronique

URL : https://journals.openedition.org/tc/568

DOI : $10.4000 /$ tc. 568

ISSN : 1952-420X

Éditeur

Éditions de l'EHESS

\section{Édition imprimée}

Date de publication : 1 novembre 1995

ISSN : 0248-6016

\section{Référence électronique}

Rhazi Attabou et Robert Chabot, "Outils intelligents et compétences élargies des opérateurs », Techniques \& Culture [En ligne], 23-24 | 1995, mis en ligne le 09 décembre 2005, consulté le 29

septembre 2022. URL : http://journals.openedition.org/tc/568 ; DOI : https://doi.org/10.4000/tc.568

Ce document a été généré automatiquement le 29 septembre 2022.

Tous droits réservés 


\section{Outils intelligents et compétences élargies des opérateurs}

Rhazi Attabou et Robert Chabot 